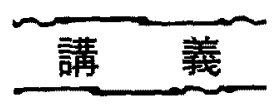

\title{
コポリマーブレンドの構造とレオロジー特性（その 1)
}

\section{1. 序論}

高分子村料の発展方向として，新しい物質の合成歹考 えられるが，需要の多粎化，諸物性の調和（配合原料品 稞の增加)，開発の容易性から見て，ポリマーブレンド の重要性はますます增加すると思䄱れる。また原料品種 とくに共重合物の種類が豊富になることはプレンドの可 能性を助長するである5。

ポリマーブレンドは徒来より鉒料やゴム工業では広く 行われてきたが，近年は瀻維，フイルム，プラスキック の分野でる盛んになる兆候がある。たとえば，ポリプロ ビレンの染色性、コンジュダート紡糸による瀻維の㨢縮 性, ポリオレフィンフィルムの低温特性, ポリ塩化ビ二 ルコンパウンドやポリスチレン樹脂の啝撃性などの向上 に関し、多数の特許が提出されている。

一般的にポリマープレンドでは，熱力学的に見て，高 分子であるという本質によって混合によるエントロピー 変化が少いので, 混合煌吸熱が大きくなと相溶し 難く，最近の発表によると，フィルムの透明性や溶液の 均一性加見て，150組中 14 組しか相溶しなかっだ。 その内、コポりマーを含むるのが 10 組あったことは， 共重合によって数種の官能基を併有する外，ポりマー間 の相互作用が变ったこ之が考えられる。

また完全に相溶しなくとる，共通の重合単位を有する 場合に，ちる範囲に㔚ける相溶性が考党られ，ブロック 共重合物にその例が報告されている2)。また別の見地よ り，共重合物は重合単位の分子内ブレンドと考克れば， その組合わせ方法の形式一ランダム,ブロック，グラフ

\footnotetext{
Structures and Rheological Characteristics of Copolymer Blends

* TOSHIKAZU FUJIMURA 山形大学工学部高分 子化学科数授.工博

** KENJI IWAKURA

*** KENKICHI MURAKAMI

学研究所教授・工博

**** TOHRU TAKAHASHI

" 講師・工修

東北大学韭水溶液化 "大学院修士課程
}

\author{
藤村敏一* ・岩倉蜸次 ${ }^{* *}$

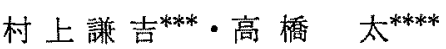

トーによって,ブレンドに対する挙動が変り得るである 万。ランダム共重合では，マクロに見れば均一で古る が，ミクロで怯不均一であり，共重合率の影響が大きい と考えられるが一方の成分が少いと，連続単位数 (Sequence length) が短かく，相溶珄への影響が少いと見ら れる。ブロック共重合物は各成分の連続単位数が長いの で共重合率が低くてもホモポリマーのブレンドに近い部 分が势り，耐成分の相溶性分悪いと，共重合物分子自身 が多相構造 (domain) を有し，むしら他のポりマ一分子 と相溶する可能性がある。グラフト共重合物はそのグラ フト長やグラフト頻度汇よって，ランダム，ブロックの いずれか㳊近い性状を示すと考劣られる。したがって今 後予想される共重合技術の進歩や品種の增加を併せ考光 ると，コポリマーのプレンド瓦展を期待し得る。

ここで混合の概念を検討すると, 総体均一性 (Gross Uniformity) 上生地 (Textuae) が考克られている3)。 総体的均一性怯試片の組成上配合率との盖の分布を無秩 序分布と比较した混合度 (Mixedness) として示すもの であり，生地は成分に隣接して他成分の存在する確率索 たは相関䋆数と距離の関保として示している。したが。 てポりマーブンンドの構造を考党るとき, 試料の規模, 分散単位が問題になる。相溶性が透明性なと観測手段に 依存している面上，ポリマ一の分子構造の面を考光合わ せて，次の段階が考光られる。

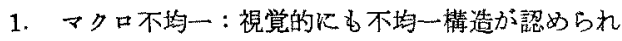
るもので栍層品などがこの例で，分散規模は $10 \mu$ 以上 でする。

2. 光学的不均一：肉眼では均一に見学るが，不透明 なるで分散単位は可視光線の波長以上 $0.5 \mu$ 以上の場 合であって，ABS 樹脂はこの例伛なる。

3. ミセル不均一：透明で放るが $0.5 \mu$ 以下の分子集 団が分散単位として認められる場合で，MBS と PVC

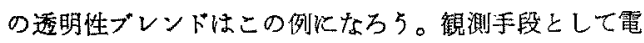
子題殿鏡やX線回折を用いる。

4. 分子均一：分子分分散単位として，各成分が同一 の確率で分布する場合で，組成に分布のある共重合体や 
置換化合物汇起り得る。

5. セグメント均一：共通な重合単位を有寸る場合，

例党ば雷合度分布を有する同族列とか，ブロックポリマ 一などの場合で，試料の错測規模として， $1 \mathrm{~m} \mu$ 程度を 採用したとき，少くとも局部的に均一性が考えられる。

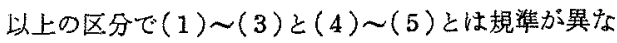
り，高分子で性 $0.5 \mu$ 程度の分子鎮長も考えられるし， またコポリマーでは流動中には，あるセグメントを見る と同一確率で，マトリックスと存在し得るが，分子単位 としては，分布確率が不均一となる場合があり部分的な 相溶性も考えられるなど，上記区分の数種が併存する場 合も教えられる。この実証については今後の問題であ 万。

物性面も以上のような構造のあり得ること，また分子 内にいるいるな官能基が併存することを考えると，成分 の特性を加成しては得られない特異な現象が起り得る。 このち面の研究結果はまだ多くはないが，紡系や成形加 工上重要な融液に関するものと，繁品の使用特性上重要 な固体に分けて紹介したい。ただし，複屈折などの光学 特性や，檕移点などの熱的特性，䉓磁気特性にる特異な 現象が考えられるが，今回はレオロジーに焦点をしぼり tい。

\section{2. 而液レオロジー特性}

熱可塑性滈分子の加工に括ける融液の流動に対して間 題となるレオロジー特性は，粘性抏よび弾性とこれらの せ九断依存性，温度依存性，粘性と弹性の比としての緩 和時間，流動の安定限界，メルトストレングスなどがす る。これらは加工速度，压力，濫度などの作業条件や， die swell, Melt fracture, 収縮なと加工物に大きな影 響を与えている。これらの法則については，別の文献に 譲り、ここではポりマープレンドについて発表されたる のを紹介したい。ただし，ブレンドを広埕化考劣れば， 単分散の分別物のブレンドスるが，これはむしろ分子 量分布の問題となるので，省略与るから，その文塥を参 照されたい゙。コポリマーのレオロジー特性は，分子内 ブレンドとも考光るので，先淿れることとする。

(流動形式として定常流, 振動流の外, クリープ, 応力 徐和もあるが，これらの報告は胃当らないので除く。)

$2 \cdot 1$ コポリマー融液のレオロジー特性

(A) ランダム゙ポリマー

a) エチレンー酷酸ビニル共重合物（以下 EVA）：藤

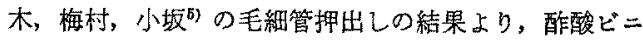

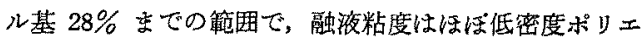
チレンと同様な性状を示すが，しかし问一重量平均分子

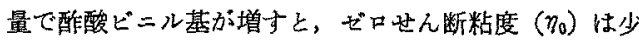

し低下する。せ九断依存性は分子量分布の影響り考克な ければならないが，分子量分布の狭いEVA が分子量分 布の㕕い低密度ポリェチレンより，低せ九断速度に打け る粘度が高く，せん断效果が強い。

メルトフラクチャーはポリエチレンと同様に流入時の 弹珄效果と考克られ，限界粘度とメルトインデックスは 直楾関係を示した。

中尾，沢田到によるとレオゴニオメーターによるゼロ せん断粘度とメルトインデックスを比較した結果では， 共重合率，メルトインデックスに対し，せん断体存性は 変らない。をたゼロせん断粘度の温度变化による活性化

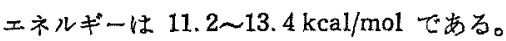

著者らクが市服品をレオゴニオメーターで測定した結 果では, 高密度ポリエチレンに比し，EVAは，粘度か $\eta_{0}$ の 1/2 になるずり速度の值が高く，粘度の対数がせん 断速度の㱛数化対し低下する割合はやや小さい。定常流 コンプライアンスはやや低い。

b）ブタジェンスチレン共重合物：Kraus, Gruver ${ }^{8)}$ は第3アミンを加壳てランダム化した一定共重合率（3： 1）の試料索毛細管から押出した結果より，ゼロせん断 粘度は両成分の中間よりあまり外れず，分子量の3.4 乘 に比例し，せん断速度による変化は分子量, 温度の影響 が注とんとなく，単分散ホモポリマーと同様であったが これは分枝がなく，分子量分布が怗いためと考えてい ‡。

c） エチレンープロピレンジェン三元共重合物：

Shin ${ }^{9)}$ の共重合比の暴なるる系列の分別物およびそのブ レンドの毛緗管押出しの結果では，网一せん断応力ての 粘度は分子量の3.6 策に比例し，せ九断による粘度低下 は応力と分子量分布で定亦り，Bueche D楥和時間に上 る分子量や温度の影響は示されず，Graessley の善嘧度 絡み合い系のゼマせん断速度と楥和時間の関係が見られ る。分子量分布の影響注高重合度部分の影響が大きく $(Z+1)$ 平均が関係する。

d）エチレンメタクリル酸共重合断

坂本, Macknight, Porter ${ }^{10}$ 《遊離酸とその Na, Ca 塩の共重合物をレオゴニオメーダーの回転振動法と定常 流法で䀦定した。イオン化していない酸共重合度物では 温度一時間の重称わせが可能であるが，イオン化して いる， $\mathrm{Na}$ 塩と $\mathrm{Ca}$ 塩共重合物では，これらが成立しな い。楥和関数をみると非イオン化酸共重合物は流動域の み見られたが，イオン化した塩共重合物はゴム状平坦域 も見られる。これさり温度が上るとイオン化領域が移動 し易いことになる。定常流粘度は非イオン化酸共重合物 が低く，また低せ儿断速度て，Na 塩より $\mathrm{Ca}$-塩が相当 高くなり，電気的引力口效果を示吉。非イオン化酸共重 
合物では動的粘度の周波数依存珄と定常流粘度のせん断 速度依存性と一致するが，イォン化した塩共重合物は一 致しない。これはイオン化集合体の作用は，短距䧺運動 の反映である勳的粘度に影響しないが，長距離運動に関 する定常流粘度に現われることを示す。

活性化エネルギーは非イオン化酸共重合物ではポリエ チレンK近く，本素結合の影響は加わらない。 Na 塩共 重合物では $160^{\circ} \mathrm{C}$ 辺より急減するが，Ca 塩は低せ几断 速度で低いこれらの結果は，岸化水素媒質中にイオン集 合体が埋められている二相構造モデルに相応する。

市服イオノマーを低密度ポリエチンンと比較した， Bukhgalter, Meshcherova, Emel'yanova, Senichkina ${ }^{11)}$ の結果ではイオノマーの粘度が高く，140〜240 $\mathrm{C}$ 内の活性化エネルギーは約半分であった。

e ）ブタジニンーアクリロニトリル（カルボキシルプ ダンン) 共重合物

Royer, Baner, Collins ${ }^{12)}$ は毛細管々円錐円板型粘度 計で即定した結果，せん断速度が低くなると一定限界粘 度に近つくが, Bueche-Harding の理論式には合わな w。

せん断速度一温度の重ね合わせは，分子量分布を考え た二段の移動で可能である。極性基がはいると，粘度が 堌加し, 移動係数より求めた活性化エネルギーす高くな った。

f）スチレンメダアクリル酸共重合物

著者ら ${ }^{(3)}$ がワイセンベルグレオゴニオメーターにより 側定した結果，ゼロせん断粘度は酸共重合体に 比し，イオン化した共重合体が著しく增大し， ずり速度依存性も著しくなり，特性緩和時間は 大きくなった。

井手，長谷川 ${ }^{14)}$ の湘定によると流動の活性化 エネルギーはポリエチレンの 7〜10 kcal/mol に対し $14 \mathrm{kcal} / \mathrm{mol}$ と大きな值を示し，さらに イオン架橋ポリマーでは， $17 〜 20 \mathrm{kcal} / \mathrm{mol}$ 度であった。

（B）ブロック共重合物

スチレンーブダシンン共重合物：Kraus，Gruver ${ }^{15)}$ は共重合率一定で（スチレン 25\%) 主 鎖方向の組成分を变齐，毛科管押出しで定常流 粘度を測定した。

その結果では，鎖長方向の組成が不均一，士 なわちブロック化する程，せえ断速度による粘 度の低下が大きくなり，温度一せえ断速度の董 ね合わせが外れる。まだブロック共重合物は粘 度の温度变化が大きく，温度効果はランがム共 重合物ではせん断速度の影響は見られないか゚,
プロック共重合物は会合し易く，二次転移点以下で，網 状構造裳生ずるとしている。

Arnold, Meier ${ }^{16)}$ は SBS 型ブロック共重合物のブロ ックの長さを変古，レオゴニオかーターで動的粘度と定 常流粘度を測定した。スキレンブロックが長くなると定 常流粘度は周波数やをえ断速度加小さくなっても上昇し 秤け，一定のぜロせん断粘度に近つかない。また位相差 角の周活数による变化も複雑な举動を示す。周波数が高 くなると通常の熱可塑性の粘度変化を示し，との転移点 の粘度と周波数の皘で示す応力は，プロック長代かかか らず一定である。移動係数加ら計算した活性化エネルギ 一はポリスチレンブロックが $35 \%$ 以上で $38 \mathrm{kcal} / \mathrm{mol}$, $31 \%$ 以下で $19 \mathrm{kcal} / \mathrm{mol}$ と大差がある。とれらから， 流動機構はせん断速度によって, 領域 (domain) 部, 転 移部，熱可塑部に分かれ，頜域部ではスチレンが多いと 半連継組織，少ないと分散組成，転移部では集合体とな ると考㝋ている。

(C) グラフト共重合物

ブチルゴムグラフトポリエチレン；Hartman, Eddy, Ko0 ${ }^{17)}$ 、はポリエチレンの特性を保らながら，ゴムの柔 軟性，強勒性，弾性回復を加えた ET ポリマーの流動性 を毛細管押出しで測定した結果，グラフトしたゴム量が 多くなると流動抵抗を增し，また流出物の表面が粗にな るとせん断速度が低下し，また原料ポリエチンンの流動 性の差が㩊され，50\%グラフトすると高密度と低密度 の差が認められなくなった。

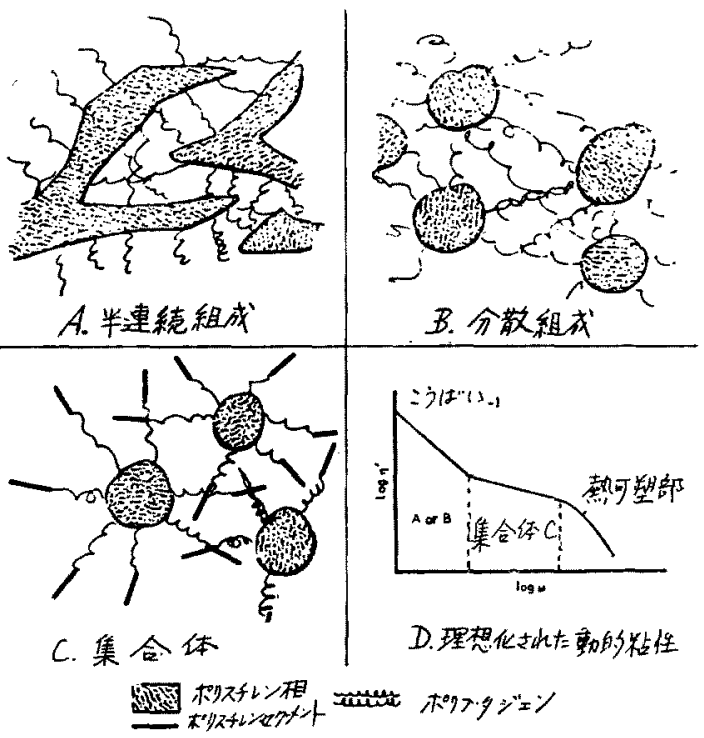

第 1 図 SBS ブロック共重合体の理想化された椣造 
以上の点を括めて見ると，共重合体はランダムで共重 合篻位が類似するときや，少ないときはホモポりマーと

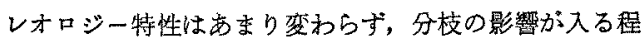
度であるが，共重合単位がイオン性であったりブロッ クであると二相構造汇よる特異なせん断効果や温度効果 を示しグラフト成分る多くなると，主銷と異った特性 を示すようである。

$2 \cdot 2$ コポリマーブレンド融液のレオロジー特性

a) ポリスチレンーゴム系

白木，関本 ${ }^{22}$ 方毦細管押し出しより求めた見か忛粘度 は，せん断速度を考虙していないが，共通成分を有する スチレンーブタジェンゴム，ハイスキレンゴムの共重合 体を加えた場合，対数平均值より高く，メルトフラクチ ヤ一を生じ易く，その他のアクリルゴムニトリルゴム， 共重合物を加克た場合は，湿合量が少小と対数平均值よ り高く，混合量が多い之低い。位相差顕微鏡に上る解察 結果も併せて, 前者は相溶性が高く, 並列混合モデルに 近いとしている。

b) ポリスチレンースチレングラフトボリブタジェン 系：上記と同じ研究シリーズで，グラフトスチレン量 を增すと見が粘度が高くなりメルトフラクチャーを 生じ易くなり，ポリブダジェンの見かけ粘度が高いもの またはゲル化したすのをグラフト原料に用いたとき，粘 度が低下し，メルトフラクナャ一党生し難くなることや ロール混練により粘度が低下しゲル化することを認め， これらは分散状熊が直列モデルに近くなったためと考兄 ている。

c) ポリエキレンーゴム系：

Nrtov, Peeva，Djagarova ${ }^{26)}$ らは毛細管押し出しに より、ポリエチレンアジペートとポり酶酸ビ二ル，特よ びポりィキルメタアクリレートの混合物，さらに落リ土 チレンセバシネートとポリメチルメタアクリレートの混 合物の場合，ポリエチレンに天然ゴムを加える上きと同 じく，見かけ粘度が混合率炕対して加成性から外九，極 小を示夏場合を認め，流動の活性化エネルギーの差によ って説明している。

d) ポリ塩化ビニルーニ゙ム系:

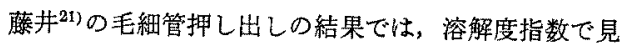
た親和性の堂いニトリルーブタジェン共重合ゴムを加え たときは、ポリメチルメタアクリレートやポリ塩化ビ二 ル自身を号芝たときと同しく，対数粘度拉よび，その活 性化エネルギーは加成性を示し，親和性の低いェチレー ンプロピレン共重合物は，ポリスキレン，ポリエチレン ポリブタジニンのときと同様, 加成性から大きく外れ， $\mathrm{ABS}$ ，エチレンー䣫酸ビニル，塩化ビニルービニル高釉脂 肪酸エステル共重合体は,ポりウレタン,アタリル系樹脂
と共に中間の挙動豆示した。以上の研究では、せん断速度 考慮していないので，その影䇾による僱りがあり得る。

Dimitrov, Marko, Pazonyi ら ${ }^{2 n}$ が一定圧で毛細管よ り押し出し見かけ粘度を求めた結果によると、アクリロ ニトリルゴムではアクリロニトリル含有率の少い方が粘 度低下が著しく，その温度変化が少ない。塩素化ポリエ チレンては塩素含有率の少い方が粘度低下が著しく，ま た牙子量の低い力が粘度低下が大き，温度変化が少 い。基準となるポり塩化どニルの 值か゚高いとき粘度は 高くなるが，その增加は，アクリルゴムでは、アアクリル ニトリル含有量の高いもの，塩素化ポりェチレンでは分 子量の高いるのを加えたときが著しい（またスルフオ塩 素化ポりエチレン,ポリクロロプレン, エポキシ化大豆 油を加えたものは粘度が增加し，ポリイソブチレンは減 少するが，添加物の粘度が不明であるから，一般的に志 える疑閔である。

Malpass ${ }^{25)}$ はポリ塩化ビニルまたは塩化ビニループロ ピレン共重合物に ABS を配合し，プラストグラフで测 定した結果，融解が速くなり，混練中の粘度が低く，摩 操熱発生が少く，温度均一となる。押し出しでは粘度が 上界し、メルトストレンダスが高くなり，ハラス效果が 減少すると報告している。

e ） ポリエチレンーエチレン・酿酸ビニル共重合物 (EVA)系：著者 $ら^{7,13)}$ はエチレン基を共通とし，極性の

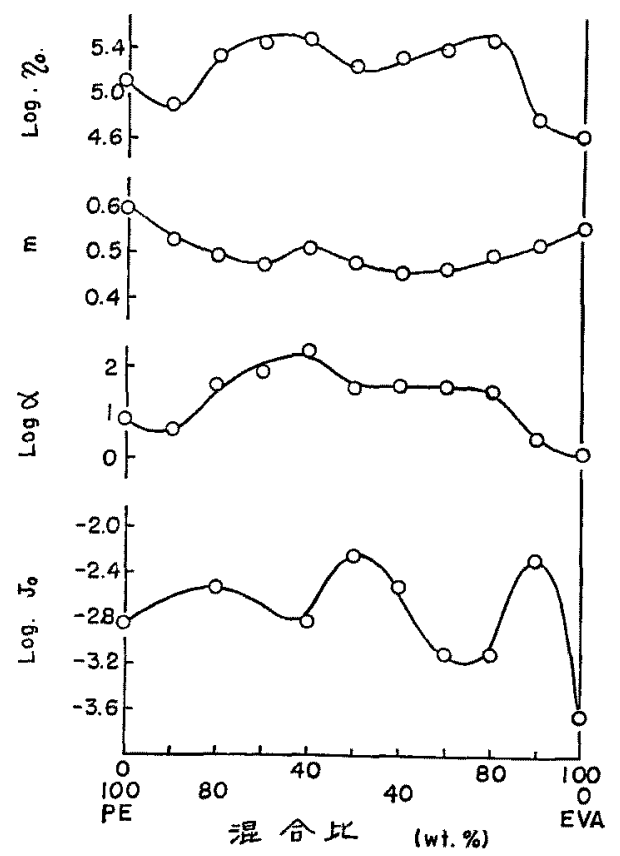

第 2 図粘性扰よび弾性のパラメーータと涅合比の関续 
異交る共重合成分をるつ混合系としてレオゴニオメータ により測定した結果，ゼロせん断粘度とコンプライアン スは混合密に対し，一般には 2 個の極大示し別にエチ レンの多い方で極少を示すことも男る。この場合，低せ ん断速度で非ニュートン性を示し始めるが，高せん断速 度における低下は少いことを認め，さらに毛細管押し出 しにおいて，バラス效果や流入王損失から求めた弾性率 外注対応寸る変化を示すことを確めた。

f）ポリエチレンーイオノマー系:

毛細管流動比和ける見かけ粘度，ハシラス効果は， EV Aーポリエチレン系と類似の变化を示したが Power law の構造粘性指数, 流動の活性化エネルギーは混合率に対 し，ほ浪加成的であっだの。せん断速度はレオプニオメ トリより高いため差が少くなると考えられる。

g) EVA-イオノマー系 :

毛細管押し出しにおけるぐラス效果，末端補正による 弾性の变化は，上記二系と同様であるが，漉合率に対す る極大の位置，大きさがほ济対称的であった。構造粘珄 指数の加成值よりの外孔は小さかった

h) ABS, AAS :

これらは，スチレン・アクリロニトリル，スチレン・ ブタジェン（またはアクリルエステル）の共重合物のブ レンドや，これらのダラフトなと多種多様なるのが市販 されているがそそのレオロジ一特性は射出成形のスパイ テルフロー試験など実用的な報告が士である。

Pawlowski28) は Ebneth ${ }^{29)}$ の固液二相モデルが流勳 長を視定するとの考えに対し，粘度の温度梦化によって

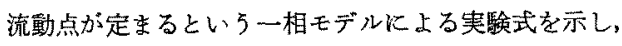
宽然と一致すると述べている。

Bergen, Morris $5^{90}$ は ABS 樹脂の融夜粘度と応力 楥和の測定を付い、これと SAN 樹脂自身, これにグラ フトしていないゴム粒子を加党た系，执よび純グラフト

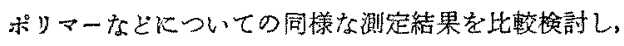
ABS 融夜のレオロジ一特性㤝，SAN マトリックスの特 性と，その中に不連継なゴム貿粒子が存在すこるとによ る影響と，ゴム質粒子の表面に多くついているグラフト 鎖のからみ合い効果が縕合されたすのであると説明して いる。

Scalco, Huseby, Blyer $5^{31)}$ は, ABS 澍脂の粘弾性 の温度依存性が，他の多くの非晶性ポりマー之類似する ことを翏め，さらに動力学的弾性率と緩和スペクトルか ら求めた流動曲線が实湘と台い, ABS 樹脂はボリエチ レンと此㜞して，高せえ断速度における流れの乱れが少 く，成形加工性が良好であり，回復性せ几断ひずみが小 きく，非晶性であるため，製品中の牫留ひずみが少いと 報告している。
Bergen ${ }^{32)}$ はムーニー粘度計を改良したレオメーター による，ABS 樹脂の流動曲線が毛細管レオメーターに よる測定值と一致すること，さらに多種の ABS 樹脂の 最低成形可能圧力とムーニ一指示値とが直楾閣係を示す ことを確め，ムーニー粘度計により成形性を予測できる と報告した。

著者ら ${ }^{13)}$ は，AAS 樹脂の一例について、レオゴニオ メーターに上り見か子粘度を測定し, 非ニュートン性は 低世九断速度で現われるが，その後のせん断速度依存珄 は少いこと，温度依存性が少いことを楒め，AAS 樹脂

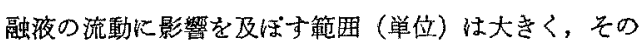
分布は広々，不均一性が大であろらと推定した。

これらの結果をまとめてみると，コポリマーブレンド の融液レオロジー特性は，その成分の相溶性，親和性が 高いとき通常の分散系と違った暴常な挙動を示してい る。また従来の報告では毛細管押し出しでせん断速度が 比較的高い所で測定しているので，ぜロせん断粘度と比 し，組成による変化が大きくないし，せん断速度や温度 の効果; 弾性に関係する効果 (パラス効果, 楥和現象, メルトフラタチヤー）なとに特翼性が著しいが，これら を検討した報告が少いので，今後の研究に待つ点が大き Wo

ことに共通の重合単位を有するブレンドの場合は，七 グメント間の部分的相溶化よる相互作用の增大が考光ら れる゙ので影響が大きくなるよ5で，構造論や固体物性 諭との関係も加えて考察することによって，ポリマーブ レンドの特性に対する原則を明らかにし得るであるち。

文 献

1) R. J. Petersen, R. D. Corneliussen, L. T. Rozelle ACS Polym. Preprint, 10, (1), 385 (1969)

2) G. Riess, J. Kohler, C. Tournut, A. Bandret ; Makromol. Chem. 101, 58 (1967)

3) J.M. McKelvey ; Polymer processing, p. 304, J. Wiley, New York (1962)

4）小野木重治，升田利史郎；离分子，17，640(1968)

5) T. Fujiki, M. Uemura, Y. Kosaka; J. Appl. Polym. Sci., 12, 267 (1968)

6) 中尾一宗, 沢昍重政; 高分子学会年会講演要旨集 19. 307 (1970)

7）藤村敏一, 岩倉蜸次; 高化, 27, No. 301,323 (1970)

8) G. Kraus, J.T.Gruver ; Trans. Soc. Rheol., 13, No. 3, 315 (1969)

9) C.K.Shin ; Trans. Soc. Rheol., 14, No. 1, 83 (1970)

10) K. Sakamoto, W. J. Macknight, R. S. Porter ; $J$. Polym. Sci., 8, 277 (1970)

11) V. I. Bukhgalter, F. F. Meshcherova, V. P. Emel'yanoVa, I. I. Senichkina; International Chemical Engineering, 8, No. 1, 104 (1968) 
12) R. J. Royer, W. H. Baner, A. Collins; Trans. Soc. Rheol., 10, No. 2, 545 (1966)

13）藤村敏一，岩会留次; 東北大非水研研究発表会講 演要旨集, $22(1970)$

14）井手交雄，長谷川章；高分子，18，No. 211，712 (1969)

15) G. Kraus, J. T. Gruver ; J. Appl. Polym. Sci., 11, 2121 (1967)

16) K. R. Annold, D. J. Meier ; J. Appl. Polym. Sci., 14, 427 (1970)

17) P.F.Hartman, C. L.Eddy, G. P. Koo ; $S P E$ Journal, 26 [5], 62 (1970)

18）藤柇敏一，岩會蜸次；工化，73，No. 7,1641 (1970)

19）藤村敏一，岩會蜸次；緒維学会誌，26，No. 10 , (1970)

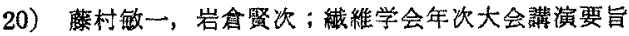
集, p. 50 (1968)

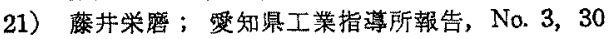
(1967)
22）白木英太郎，関本羲一；工化，65， No. 3，440 (1962)

23) L. C. Anderson ; J. Polym. Sci., 43, 423 (1962)

24）野村繁三；离化，12，527（1955）

25) V. E. Malpass ; Modern Plastics, 47, No. 1, 131 (1970)

26) M. Natov, L. Peeva, E. Djagarova ; J. Polymer Sci., RARTC, No. 16, 4197 (1968)

27) M. Dimitrov, R. Marko, T. Pazon; Plaste und Kautschuk, 16, No. 7, 491 (1969)

28) J. Pawlowski ; Kunststoffe, Bd. 60, 37 (1970)

29) H. Ebneth, K. Boehm ; Plastverarbeiter, Bd. 19 261 (1968)

30) R. L. Bergen, H. L. Morris ; International congress on Rheology, ABSTRACTS, 103 (1968)

31) E. Scalco, T. W. Huseby, L. L. Blyler, Jr.; J. Appl. Polymer Sci., 12, 1343 (1968)

32) R. L. Bergen, Jr.; SPE Tech. Papers RETEC. (Hartford Conn.) 25 (1964)

\section{最 新 刊}

<化学增刊 45>

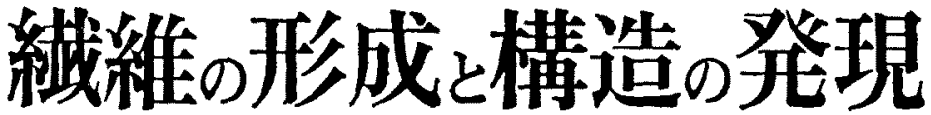

湿式紡系と乾式紡系

縤維学会編・B5判・定価 1500 円

人造繊維は製造条件を変化させることにより，䋐維の構造を变化させ， 性質に微妙に反映させることが可能で，特に紡系過程の複雑な湿式・乾 式紡系ではこの可能性は大である. 本書は, “蟣維の形成と構造の発現” （化学增刊 39）の続編として，これらの点を中心にわが国最高レベルの 研究者か人造瀻維の研究成果を披瀝し，平易に解説する。

\section{《主要目次》}

1 序馀 溶融紡系について (滰沢 章)

2 ビスコース法スフの紡系之䋊維構造 (原 弘 道)

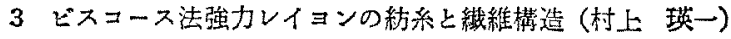

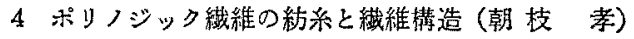

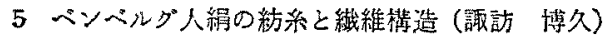

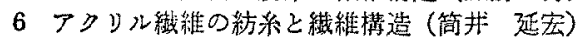

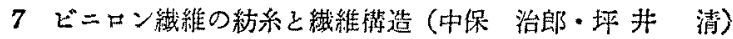

8 アセテート人編の紡系と綫維構造 (高久 明)

9 ポり塩化ビニル維維の紡系と維維構造 (高山実)

10 ポリ程化ビニリデン瀻維の紡系と練維形成過程 (朝比奈光雄)

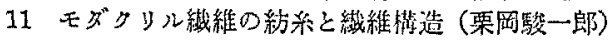

【図書目録進呈】 604 - 宗都市印京区柳馬場御池下ル T E L (211) 8391 (代)：振替京都 5702 